\title{
Secondary Metabolite Profiling of Four Host Plants Leaves of Wild Silk Moth Attacus atlas L.
}

\author{
Lisna Hidayati ${ }^{1}$, Tri Rini Nuringtyas ${ }^{1, *}$ \\ ${ }^{1}$ Laboratory of Biochemistry, Faculty of Biology, Universitas Gadjah Mada, \\ Jalan Teknika Selatan, Sekip Utara, Yogyakarta 55281, Indonesia
}

\begin{abstract}
Secondary metabolites may affect insect herbivores' host plant preferences. Attacus atlas L. larvae are known have a wider variety of host plants compared with other members of the Attacus genus. This research compared the metabolic profiles of four A. atlas host plants: keben (Barringtonia asiatica (L.) Kurz), dadap (Erythrina lithosperma Miq.), gempol (Nauclea orientalis L.), and soursop (Annona muricata L.). Leaves were collected from Sawit Sari Research Station, Yogyakarta. Terpenoid was extracted by macerating the leaves in ethyl acetate and subjecting them to GC-MS analysis, while alkaloid, tannin, and flavonoid were extracted through percolation. Total alkaloids, tannins, and flavonoids were measured using spectrophotometric analysis. Multivariate data analysis using PAST ver. 3.0 was performed on the GC-MS data. Based on the PCA scatter plot of the GC-MS data, keben leaves were clustered separately from the other three leaves by PC1. Dadap and gempol leaves were clustered together due to the phytol content while caryophyllene was detected only in soursop leaves. Neophytadiene was detected in all of the leaves, suggesting that this terpenoid may serve as a signal to locate the host plants. Keben leaves contained the lowest alkaloids and highest tannins and flavonoids compared with the other leaves. These secondary metabolites may determine the host plant suitability for culturing the $A$. atlas.
\end{abstract}

Keywords: Attacus atlas L., GC-MS, host plants, secondary metabolites

\section{Introduction}

Wild silk Atakas moth Attacus atlas L. is known as a silk producing insect, aside from Bombyx mori, the primary producer of mulberry silk. Although this wild silk moth sometimes consider as a pest for cultivated plants, however its fiber silk character is acknowledged to be better than the mulberry silk especially for its soft, cool, not easily crumpled, better hot resistance and also possess antibacterial activity (Akai, 1997). Wild silk fibers have a porous structure, and the basic color depends on the species and its feed. Atakas's silk is very potential to be promoted as an export commodity either as raw material or its derivatives product (Situmorang, 1997). This is supported by the

\footnotetext{
*Corresponding author:

Tri Rini Nuringtyas

Laboratory of Biochemistry, Faculty of Biology, Universitas Gadjah Mada, Jalan Teknika Selatan, Sekip Utara, Yogyakarta 55281, Indonesia

E-mail: tririni@ugm.ac.id
}

possibility of $A$. atlas moth to be cultured like tasar silkworm and eri silk worm. Since 1992, A. atlas has been maintained in culture under screen house conditions in the Entomology Laboratory, Faculty of Biology, Universitas Gadjah Mada, Indonesia. However, since optimum artificial diets have not been developed, culturing in the field using their natural host plants is preferred.

The content of secondary metabolites contributes on the insect decision of their host plants. High alkaloid and tannin content in the leaves tend to be avoided as they disturbed the protein digestion activity. In contrast, the insect feeding activity is closely related to phagostimulant volatile compounds produced by the plant. In addition to the shape and leaf size, colour and smell affect the insect preference for visiting and laying eggs on a certain plant (Edgar, 1984).

Natural feed plants of $A$. atlas larva are recorded as the most various species than other members of the genus Attacus. In Indonesia there are over 40 plants considered 
as the A. atlas host plants (Kalshoven, 1981). A previous study reported that among these forty plants, four plants were recognized as the most preferred plants: keben Barringtonia asiatica (L.) Kurz, soursop Annona muricata L., dadap Erythrina lithosperma Miq., and gempol Nauclea orientalis L. Keben was reported as the best supporting host plant for larva life of $A$. atlas (65\%) compared to gempol $(17 \%)$, soursop $(10 \%)$, and dadap (10\%) (Purwanto and Garjito, 2002). It is possible that these plants produced similar metabolite which plays role as a signal to recognize their host plants.

In this study, we compared the secondary metabolites profiles as well as alkaloid, flavonoid and tannin contents of the four host plants of wild silk moth A. atlas including keben, dadap, gempol, and soursop, in order to identify the compounds which may serve as a signal to locate its host plants.

\section{Materials and Methods}

\section{Leaves Material}

Leaves of the four previously mentioned host plants were collected from Sawit Sari Research Station, Faculty of Biology, Universitas Gadjah Mada. The collection was started from the fifth leaves of every branches. These was done to ensure that all leaves had reached the maturity stage. The leaves were then air dried and then dried in an oven at $70^{\circ} \mathrm{C}$ until constant weight. The dried leaves were powdered using a blender and then kept in the dried container for extraction.

\section{Leaves extraction}

\section{Ethyl acetate extraction}

The extraction was done by following the procedure of Feeny et al. (1998) with modification. An amount of $5 \mathrm{~g}$ of powdered leaves sample was macerated using $30 \mathrm{~mL}$ ethyl acetate in the Erlenmeyer flask and continuously stirred for $15 \mathrm{~min}$ at $38^{\circ} \mathrm{C}$. The mixture was filtered using Whatman paper No. 1. Ethyl acetate phase was separated using liquid-liquid extraction by adding $10 \mathrm{~mL} \mathrm{5 \%}$ $\mathrm{KOH}$ in separating funnel. The separation was maximized by performing the extraction three times. The aqueous phase was discarded, and the ethyl acetate phase was further extracted with $10 \mathrm{~mL}$ of $5 \% \mathrm{HCl}$ for three times. The aqueous phase was discarded, and the ethyl acetate phase was concentrated to $20 \mathrm{~mL}$ on a water bath at $55^{\circ} \mathrm{C}$. The mixture was further centrifuged at $4000 \mathrm{rpm}$ for 25 min, and the supernatant was evaporated to dryness. The ethyl acetate extract was dissolved in chloroform for GC-MS and Thin Layer Chromatography (TLC) analysis.

\section{Crude alkaloid extraction}

The crude alkaloid extraction was based on procedure of Gupta et al. (2012), with a slight modification. The dried powder leaves samples (10 g) were macerated using 10\% acetic acid in ethanol solvent over night at room temperature. Subsequently, the mixture was adjusted to $\mathrm{pH} 9$ by the addition of concentrated ammonium hydroxide solution. The crude alkaloid was extracted using chloroform and the organic solvent was separated using separating funnel. This procedure was repeated three times. The chloroform extract was dried using rotary evaporator.

\section{Tannin and flavonoids extraction}

The dried powder leaves sample was extracted using water and heated for $10 \mathrm{~min}$ for tannin extraction while the flavonoids extraction was done by macerated the dried leaves sample with $80 \%$ methanol for overnight at room temperature. The supernatant of both extractions was dried using rotary evaporator (Hosain et al., 2013).

\section{Gas Chromatography-Mass Spectrometry (GC-MS)}

The Gas Chromatography-Mass Spectrometry (GC-MS) analysis was performed in GC-MS QP2010S SHIMADZU using Rtx-5MS column (fuse silica) in the Laboratory of Organic Chemistry, Faculty o1f Mathematics and Natural Sciences, Universitas Gadjah Mada. The GC-MS condition was as follow: $320^{\circ} \mathrm{C}$; length $30 \mathrm{~m}$; diameter $0.25 \mathrm{~mm}$; detector FID; gas He 185.6 $\mathrm{kPa}$. GC-MS analysis resulting in chromatogram was compared to complete 
library of Computer Library NIST62.LIB and WILEY7.LIB. Percent of the total compound was calculated using Eq. 1.

$\%$ total $=\frac{\text { Corresponding area compound }}{\text { Total area compound }} \times 100 \% \quad$ Eq.1

\section{Total alkaloid measurement}

The total alkaloid was determined using spectrophotometric method (Shamsa et al., 2008). The crude alkaloid extract (1 mg) was diluted with $10 \mathrm{~mL}$ chloroform. The $\mathrm{pH}$ of the solution was adjusted to seven using 0.1 $\mathrm{NaOH}$. The solution was then added by $5 \mathrm{~mL}$ of BCG solution and $5 \mathrm{~mL}$ of phosphate buffer. The mixture was shaken and measured the absorbance at $470 \mathrm{~nm}$ against blank prepared as above. The standard solution used was caffeine with a concentration ranging from $0.1-1.0 \%$.

\section{Tannin measurement}

An amount of $10 \mathrm{mg}$ of the water extract of tannin crude extract was dissolved in 25 $\mathrm{mL}$ of methanol. Standards of tannins was prepared by dissolving $1 \mathrm{mg}$ in $25 \mathrm{~mL}$ of methanol. All of the solution were diluted with the same solvent $(1: 100)$, and the spectrophotometric measurements was recorded at $220 \mathrm{~nm}$ (Jain and Dixit, 2004).

\section{Total flavonoid measurement}

The total flavonoid content of crude extract was determined by the aluminum chloride colorimetric method (Chang et al., 2002). The crude extract was dissolved in ethanol to reach a concentration of $1 \mu \mathrm{g} / \mathrm{mL}$. An amount of $25 \mu \mathrm{L}$ of this mixture was diluted into $1 \mathrm{~mL}$ with methanol, following with addition of $4 \mathrm{~mL}$ of distilled water and $0.3 \mathrm{~mL}$ of $5 \%$ NaNO2 solution. The mixture was gently mixed and allowed for $5 \mathrm{~min}$ incubation at room temperature. Subsequently, the mixture was added with $0.3 \mathrm{~mL}$ of $10 \%$ $\mathrm{AlCl} 3$ solution and allowed to stand for 6 min. Then, $2 \mathrm{~mL}$ of $1 \mathrm{~mol} / \mathrm{L} \mathrm{NaOH}$ solution were added, and the final volume of the mixture was brought to $10 \mathrm{~mL}$ with doubledistilled water. The mixture was allowed to stand for $15 \mathrm{~min}$, and absorbance was measured at $510 \mathrm{~nm}$. The total flavonoid content was calculated from a calibration curve.

\section{Verification of the terpenoid content}

The terpenoid content was verified according to the method described by Gocan (2005) with some modifications. The crude ethyl acetate extract of the host plant leaves were subjected for TLC analysis. A mixture solvent of chloroform:methanol at ratio of 9:1 was used as mobile phase. The TLC plate was visualized using vanillin sulphate, subsequently the plate was heated at $110^{\circ} \mathrm{C}$ for 5 minutes to optimize the colour development. The positive terpenoid could be detected as red to purple spot on the TLC plate under visible light.

\section{Data Analysis}

To analyze the difference in metabolite profile of the host plants, principal component analysis (PCA) was performed using PAST ver 3 (Walker et al., 2011). The concentration of each compound was evaluated based on its relative intensity to the total intensity. The TLC result were analysed descriptively by observing the colour developed after spraying with detection reagent. The alkaloid, tannin and flavonoids content were analysed using ANOVA to determine the difference among the host plant species, followed by DMRT to locate the difference.

\section{Results and Discussion}

\section{Metabolite profiling of volatile compounds of four host leaves of A. atlas}

Several factors including mating behavior, space without an enemy, host-plant chemistry and leaf anatomy have been suggested to decide the feeding specificity of herbivores insect (Hagen and Chabot, 1986; Schultz, 1988). The host plant chemistry is associated mostly with secondary metabolites as their roles are varied from the defense, repellent as well as attractant (Schultz, 1988; Guil-Guerrero et al, 2000). As an attractant, host plants produce volatile compounds which serve chemical stimulus to invite or to help the herbivore insect to recognize their feed (Edgar, 1984). 


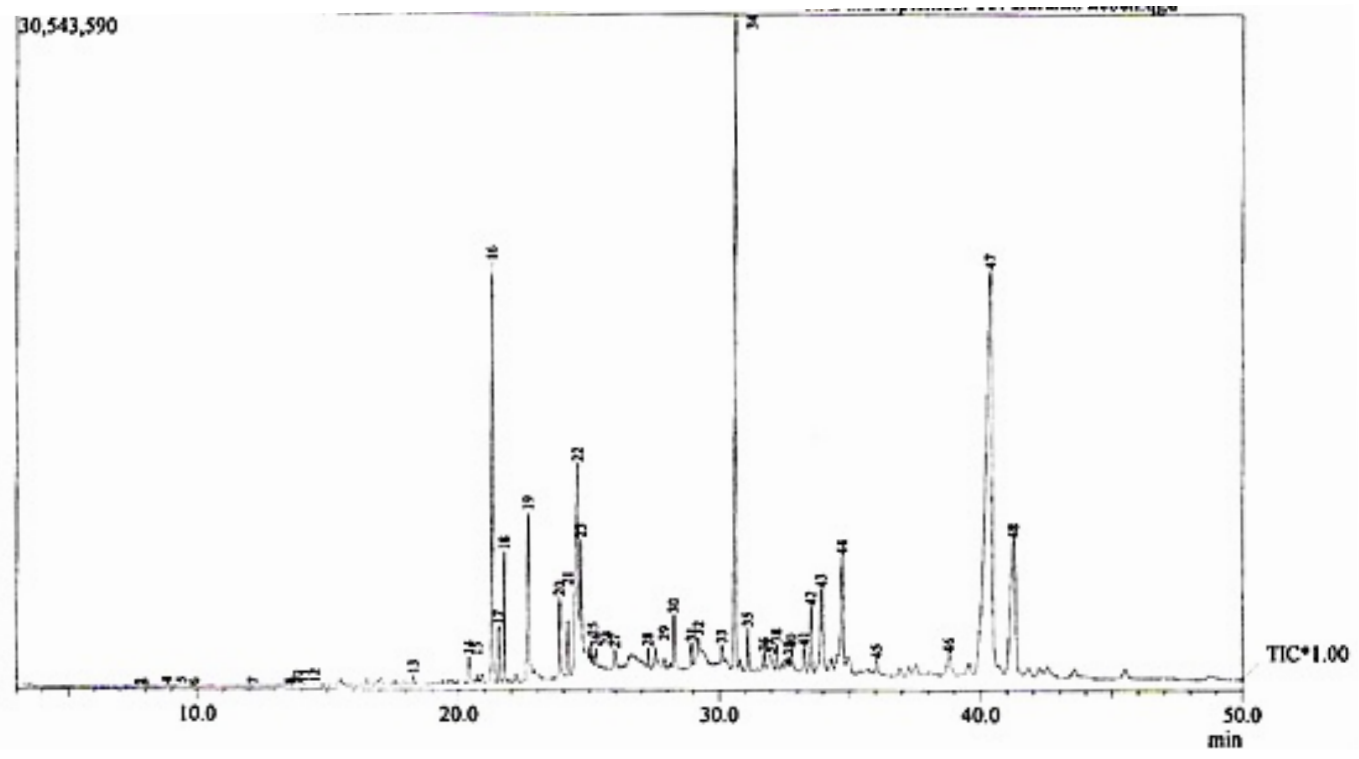

Figure 1. A representative GC-MS chromatogram of ethyl acetat extract of keben. The GC-MS was fully run for 50 min to ensure that all volatile compounds were detected.

The development of wild silk moth industry is still hampered by several factors including the host plants. Until now, very limited study has been done on how actually A. atlas moth choose its host plants. In this study, comparison of the four of the most preferred host plants of $A$. atlas was done. The study was focused on the profile of volatile compounds in the ethyl acetate extract leaves of keben, dadap, gempol, and soursop.

The result of GC-MS of the host plant leaves showed that dadap leaves contained the most various volatile compounds with 97 peaks, followed by soursop 95 peaks, gempol 86 peaks and keben 48 peaks (Table 1, Figure 1 ).

To determine the secondary metabolites profiles of the four host plants of Atakas moth, all of the peaks detected using GC-MS were subjected for principal component analysis (PCA). The PCA score plot result showed a clear separation between keben leaves and the other three leaves, Dadap, gempol, and soursop (Figure 2a). The PC1 explained 41\% of the total variation of GC-MS peaks while PC2 covers $34.3 \%$ giving in total of $75.3 \%$ of variance in the PCA score plots. This high variance value indicated the good quality of the PCA model as it considers almost all of the characters detected for the clustering. The scree plot validated the quality of PCA in this analysis (Figure $2 b$ ). Keben samples were separated from the other three host plants by the PC1. The loading plot of the PCA was used to identify which volatile compounds responsible for the separation of four host plants species. The loading plot of $\mathrm{PC} 1$ showed that 10 peaks were responsible for the separation of keben leaves from the other three host plants leaves (Figure 2c). The loading plot of PC2 showed which peaks were responsible for differentiating the soursop leaves from dadap leaves (Figure 2d).

The leaves emit small amounts of volatile compounds but when a plant damaged by insect herbivores, the volatile compounds released are risen sharply. These compounds may be different between one species to other ones. Several reports emphasized that certain volatile compounds can play an important role in signalling between herbivory insects and their host plants, so called semiochemicals (Pare and Tumlinson, 1999). Semiochemical is generally in the form of terpenoid

Table 1. Summary peaks numbers of the GC-MS result of ethyl acetate extract leaves of keben, dadap , gempol, and soursop.

\begin{tabular}{rlcc}
\hline No & Sample & $\begin{array}{c}\text { Number } \\
\text { of peaks }\end{array}$ & $\begin{array}{c}\% \text { total peak } \\
\text { area }\end{array}$ \\
\hline 1 & $\begin{array}{l}\text { Keben } \\
\text { (Barringtonia asiatica) }\end{array}$ & 48 & $859,271,033$ \\
2 & $\begin{array}{l}\text { Dadap } \\
\text { (Erythrina lithosperma) }\end{array}$ & 97 & $1,211,478,461$ \\
3 & $\begin{array}{l}\text { Gempol } \\
\text { (Nauclea orientalis) }\end{array}$ & 86 & $1,155,343,703$ \\
4 & $\begin{array}{l}\text { Soursop } \\
\text { (Annona muricata) }\end{array}$ & 95 & $1,200,539,384$ \\
\hline
\end{tabular}




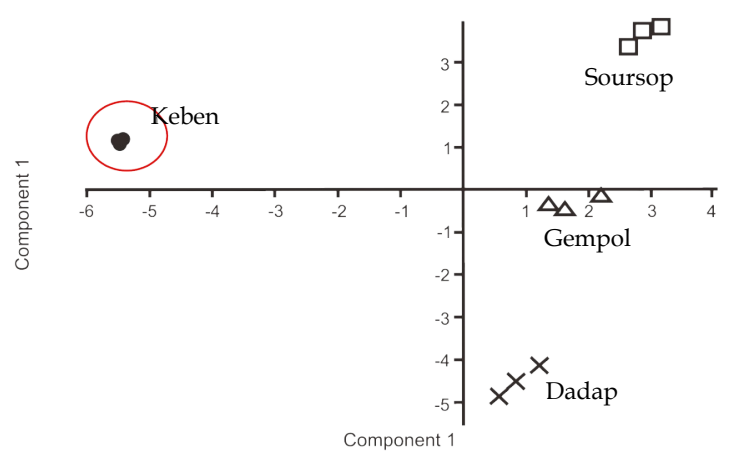

(a)

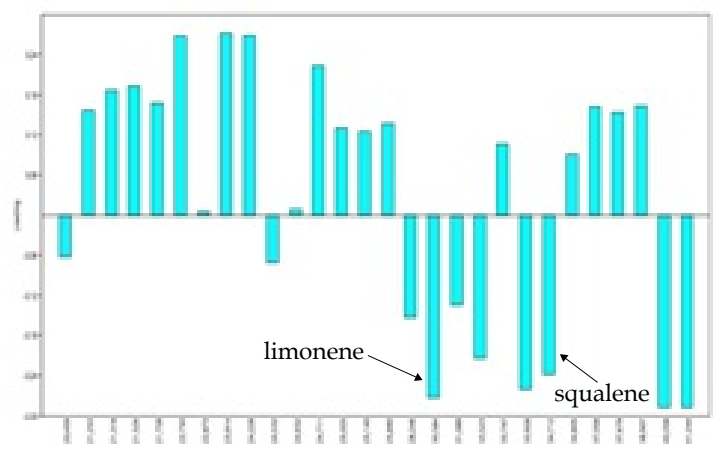

(c)

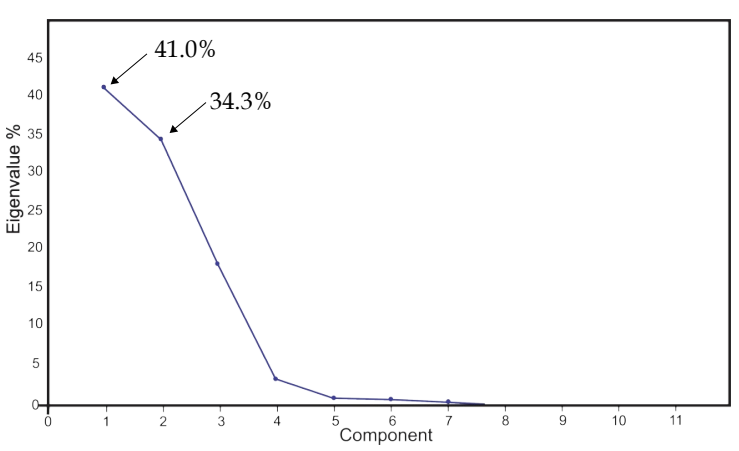

(b)

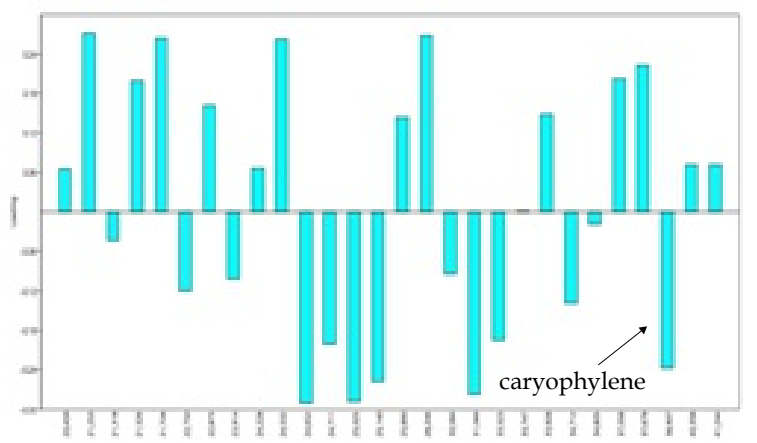

(d)

Figure 2. Score plot (a), scree plot (b), loading plot PC1 (c), and loading plot PC2 (d) of GC-MS profile of ethyl acetate extracts of four host plants leaves (keben, dadap, gempol, and soursop) of Attacus atlas.

compounds or other compounds that are volatile. In the short tail butterfly, volatile compounds known to help improve contact between insects with plants, increase the average landing and laying eggs on plants fodder (Feeny et al, 1998), and also serves to determine whether the plants are suitable as feed or not.

In this study, six major terpenoids compounds had been identified in the four host plants of $A$. atlas (Table 2). Thus, in order to verify the present of terpenoids in the four host plant leaves, the crude ethyl acetate extracts were subjected for TLC. The TLC result showed that the four extracts showed a positif result for terpenoids (Figure 3).

Among these terpenoids, neophytadiene was detected in all four host plants.
Neophytadiene is an acyclic diterpenoid. These volatile compounds have been detected in tobacco plants and various grasses. Neophytadiene along with phytol role in laying eggs on corn Sesamia nonagrioides (Konstantopoulou et al., 2004; Socolsky et al., 2003). This result suggested that neophytadiene may play a role in the signaling of Atakas moth to locate its host plants.

Remarkably, the clustering of the four host plants in the PCA score plot (Figure 2a) are in line with previous report evaluating the performance of $A$. atlas moth fed with the four host plants. Keben leaves was discovered to be superior compared to the other three host plants especially on giving a better result for larvae survivorship, cocoon quality, hemolymph protein content (Sukirno et al.,

Table 2. Major terpenoid content of four host plants of Attacus atlas.

\begin{tabular}{lcccc}
\hline Compounds & \multicolumn{4}{c}{ Relative Concentration (\%) } \\
\cline { 2 - 5 } & Keben & Dadap & Gempol & Soursop \\
\hline Limonene & 0.032 & - & - & - \\
Neophytadiene & 6.568 & 8.742 & 3.779 & $\mathbf{0 . 1 2 5}$ \\
Squalene & 14.200 & - & - & - \\
Phytol & - & 14.483 & 8.891 & - \\
Caryophyllene & - & - & - & 10.261 \\
\hline
\end{tabular}


UV $256 \mathrm{~nm}$

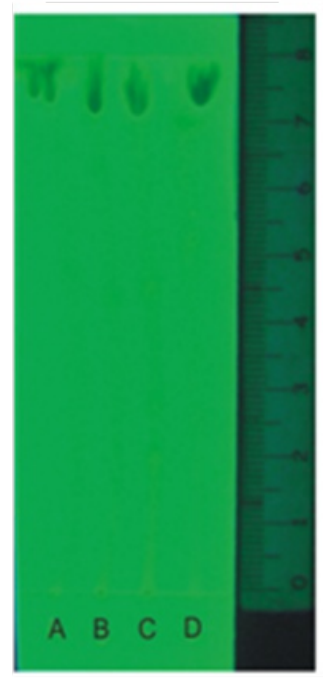

UV $365 \mathrm{~nm}$

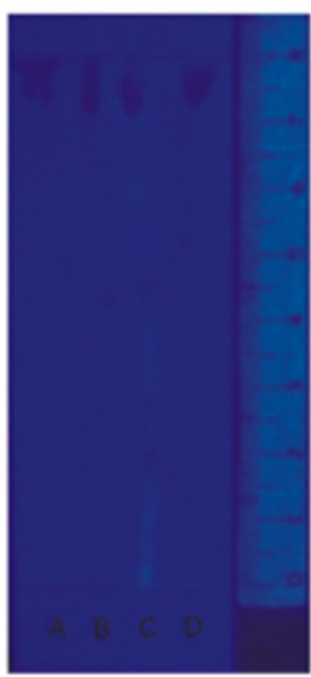

Visible

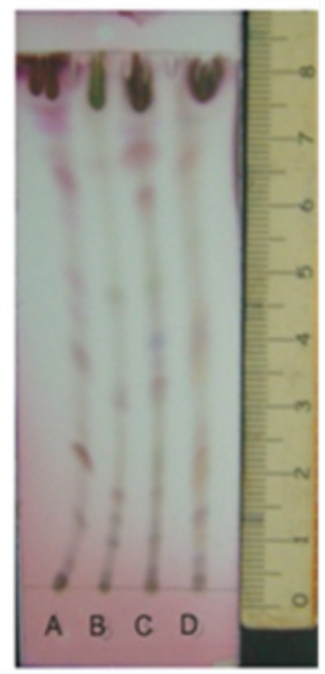

Representative diagram

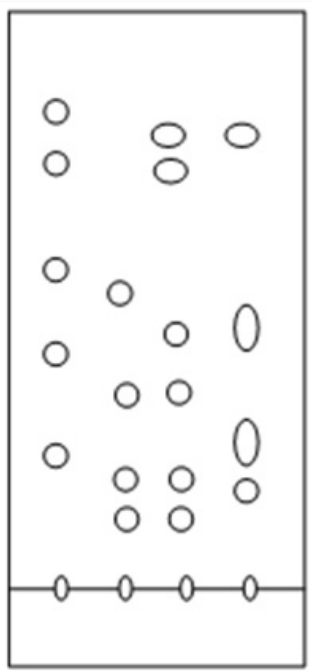

Figure 3. Thin Layer Chromatography result of ethyl acetate extract of the four host plant leaves showing positive to terpenoids: A. keben (Barringtonia asiatica); B. dadap (Erythrina lithosperma); C. gempol (Nauclea orientalis); and D. soursop (Annona muricata).

2013). In this study, keben leaves was revealed separate from the others. Based on the terpenoid content, two terpenoids were observed present in the keben leaves but not in the other, i.e. limonene and squalene. We suggest that squalene which was detected in a significant concentration may the specific compound which differentiate keben leaves from the others. Squalene as a sterol synthesis intermediate is naturally widespread in many animals and plants, including Terminalia catappa (Ting-Fu et al., 2002), and Echium sp. (Guil-Guerrero et al., 2000). Squalene may be used as plant-derived semiochemicals for host location and ovipositional probing behavior of leafminer parasitoid (Dutton et al, 2000). Dadap and gempol leaves were located in the same quadrant of PCA score plot (Figure 2a). These two host plants contained a high concentration of phytol aside from neophytadiene. Phytol was detected $14.48 \%$ in dadap leaves and $8.89 \%$ in gempol leaves. Soursop leaves which located above dadap and gempol leaves in the PCA score plot differ from the two as the leaves contained a high concentration of caryophyllene (10.26\%). Caryophyllene is sesquiterpenoid contained in many essential oils including clove. Caryophyllene has been reported serve as allomone for diverse insects such as Dysdercus cingulatus (Heteroptera), Lasioderma serricorne (Coleoptera), Omalium rivulare (Coleoptera) (Langenheim, 1994).

Alkaloids, tannin and flavonoids are known as secondary metabolites related to defense mechanism of plant (Arimura, 2009).

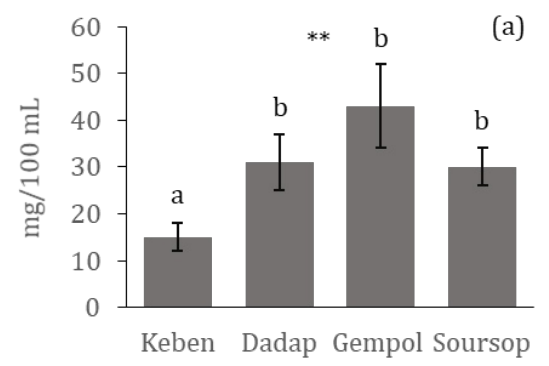

Plant species

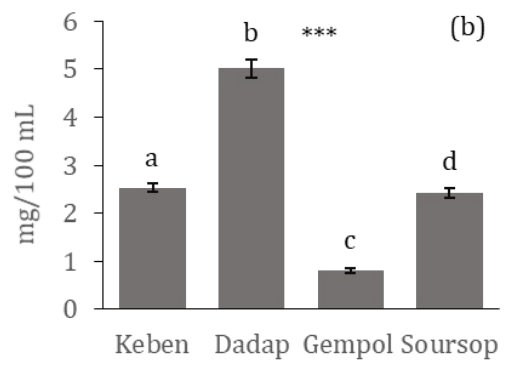

Plant species

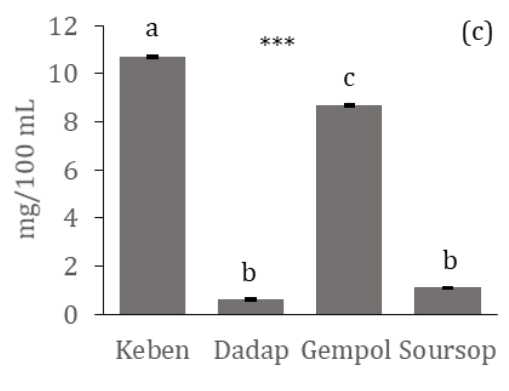

Plant species

Figure 4. The total alkaloid (a), flavonoid (b) and tannin (c) content of four host plant of Attacus atlas leaves. Data present the average and standard deviation of three replicates. Different letters denote significant differences at ${ }^{*} \mathrm{P}<0.05 ;{ }^{* *} \mathrm{P}<0.001$ ***, $\mathrm{P}<0.0001$ using ANOVA. 
Keben leaves contained the lowest total alkaloid compared with the other three host plant leaves (Figure 4). This may confirm the accumulated studies reported that $A$. atlas reared in keben leaves had a better survivorship compared to other (Sukirno et al., 2013). Interestingly, keben also contained the highest concentration of tannin followed by gempol, dadap, and soursop with comparable concentration. Tannin may serve as repellant for quenching insect as it gives an astringent effect and an anti-nutritive activity when present in high concentration. It is possible that $A$. atlas larvae can neutralize the tannin of keben, thus the high tannin content of keben leaves does not give a negative effect. Flavonoids which usually serve as the natural antioxidant showed a variable concentration among the four host plants. Flavonoids are abundant in plant leaves as it serves as protectant against both abiotic and biotic stress. This compound is also part of the natural reactive oxidative stress defense mechanism in plant which protect plants from high concentration of free radical production upon insect herbivore attack (Duttonet al., 2000).

\section{Conclusions}

It can be concluded that among the four most preferred host plants of $A$. atlas, keben leaves contained a different GC-MS profile than the other three host plants. Keben specifically contained squalene in a high proportion, whereas dadap and gempol leaves contained phytol. Caryophyllene was detected in the soursop leave in a high proportion. Neophytadiene were detected in all host plants suggested its role as a cue for A. atlas to locate the feed plant. Keben leaves contained the lowest alkaloids and highest tannin compared to the other three host plants. These may contribute to the higher survivorship of larvae and better cocoon quality when fed with keben leaves.

\section{Acknowledgements}

This work was partially supported by young scientist research grant of Universitas Gadjah Mada. Authors would also like to thanks to Suranto for his assistance in the sample preparation.

\section{References}

Akai, H. 1997. Recent aspects of wild silk moths and silk research. Paper in seminar of cooperative prospects of Yogyakarta-Kyoto. Yogyakarta: UGM Center of Japanese Studies.

Arimura, G.I., Matsui, K., and Takabayahi, J. 2009. Chemical and molecular ecology of herbivore-induced plant volatiles: proximate factors and their ultimate functions. Plant Cell Physiol., 50, 911-23.

Chang, C.-C., Yang, M.-H., Wen, H.-M., Chern, J.-C. 2002. Estimation of total flavonoid content in propolis by two complementary colorimetric methods. J. Food Drug Anal. 10, 178-182.

Dutton, A., Mattiacci, L., and Dom, S. 2000. Plant-derived semiochemicals as contact host location stimuli parasitoid of leafminers. J. Chem. Ecol., 26(10), 2259-2268.

Edgar, J.A. (1984) Parsonsieae: ancestral larval foodplants of the Danainae and Ithomiinae. In: Vane-Wright, R.I., and Ackery, P.R. (eds) The biology of butterflies. London: Academic Press Inc. pp. 65-79.

Feeny, P., Städler, E., Åhman, I., and Carter, M. 1998. Effects of plant odor on oviposition by the black swallowtail butterfly Papilio polyxenes (Lepidoptera: Papilionidae). J. Insect Behav., 2(6), 803-827.

Gocan, S. (2005) Terpenoids: analysis by TLC. California: CRC Press. pp. 1676-1681.

Guil-Guerrero J.L., Garcia-Maroto, F., Campra-Madrid, P., and GomezMercado, F. 2000. Occurence and characterization of oils rich in $\gamma^{-}$ linolenic acid, part II: fatty acids and squalene from Macaronesian Echium leaves. Phytochemistry, 54(5), 525-529.

Hagen, R.H., and Chabot, J.F. 1986. Leaf anatomy of maples (Acer) and host use by Lepidoptera larvae. Oikos, 47, 335-345.

Hosain, M.A., Al-Raqmi, K.A.S., Al-Mijizy, Z.H., Weli, A.M., and Al-Riyami, Q. 2013. Study of total phenol, falvonoids 
contents and phytochemical screening of various leaves crude extracts of locally grown Thymus vulgaris. Asian Pac. J. Trop. Biomed., 3(9), 705-710.

Gupta, R., Datta, A., and Shri, R. 2012. Extraction process optimization of tylophorine from Tylophora asthmatica Wight \& Arn. Pharmacogn. J., 4(28), 19-23.

Jain, U.K., and Dixit, V.K. 2004. Spectrophotometric estimation of tannins from Chyavanprash. Indian Drugs, 41, 462-472.

Kalshoven, L.G.E. (1981) Pest of crops in Indonesia. Jakarta: P.T. Ichtiar BaruVan Hoeve.

Konstantopoulou M.A., Krokos, F.D., and Mazomenos, B.E. 2004. Chemical composition of corn leaf essential oils and their role in the oviposition behavior of Sesamia nonagrioides females. J. Chem. Ecol., 30(11), 2243-2256.

Langenheim, J.H. 1994. Higher plant terpenoids: a phytocentric overview of their ecological roles. J. Chem. Ecol., 20(6), 1223-1280.

Shamsa, F., Monsef, H., Ghamooshi, R., and Verdian-rizi, M. 2008. Spectrophotometric determination of total alkaloids in some Iranian medical plants. Thai J. Pharm. Sci., 32, 17-20.

Situmorang, J. (1997) Optimasi susunan pakan buatan untuk pertumbuhan dan kualitas kokon ulat sutera atakas Attacus atlas L. (Lepidoptera: Saturniidae). Yogyakarta: Gadjah Mada Research Center.

Pare, P.W., and Tumlinson, J.T. 1999. Plant volatiles as a defense against insect herbivore. Plant Physiol., 121, 325-331.

Purwanto, H., and Garjito, T.A. 2002. The eggs deposition preference of Attacus atlas L. (Lepidoptera: Saturniidae) on its host plants. Poster presentation in the 4th International Conference on Wild Silkmoths. Yogyakarta 23-27 April 2002.

Purwanto, H., Widyarto, R., and Wahyudi, A. 2002. Does species of parent's host plant of Attacus atlas L. (Lepidoptera:
Saturniidae) have effect on the survivorship of progeny when reared on other plant species? Oral presentation in The 4th International Conference on Wild Silkmoths. Yogyakarta 23-27 April 2002.

Schultz, J.C. 1988. Plant responses induced by herbivores. Trends Ecol. Evol. 3(2), 45-49.

Sukirno S., Situmorang, J., Sumarmi, S., Soesilohadi, R.C.H., and Pratiwi, R. 2013. Evaluation of artificial diets for Attacus atlas (Lepidoptera: Saturniidae) in Yogyakarta Special Region, Indonesia. J. Econ. Ento., 106(6), 2364-2370.

Socolsky, C., Salvatore, A., Asakawa, Y., and Bardón, A. 2003. Bioactive new bittertasting p-hydroxystyrene glycoside and other constituents from the fern Elaphoglossum spathulatum. Arkivoc, 10, 347-355.

Ko, T.-F., Weng, Y.-M., and Robin Y. 2002. Squalene content and antioxidant activity of Terminalia catappa leaves and seeds. J. Agric. Food Chem., 50(19), 5343-5348.

Walker, V., Bertrand, C., Bellvert, F., MoenneLoccoz, Y., Bally, R., and Comte, G. 2011. Host plant secondary metabolite profiling shows a complex, strain dependent response of maize to plant growth-promoting rhizobacteria of the genus Azospirillum. New Phytol., 189, 494-506. 